\title{
The efficacy of recognising high-risk patients by nurses with the use of the Helios Score
}

\section{Skuteczne rozpoznawanie wysokiego ryzyka okołozabiegowego przez pielęgniarkę przy użyciu skali Helios}

\author{
Anita Rybicka , Arkadiusz Kazimierczak², Marta Bieniek², Sebastian Kazimierczak², Małgorzata Starczewska, \\ Elżbieta Grochans ${ }^{1}$
}

${ }^{1}$ Department of Nursing, Faculty of Health Sciences, Pomeranian Medical University, Szczecin, Poland Head of the Department: Elżbieta Grochans PhD

2Department of Vascular Surgery, Pomeranian Medical University, Szczecin, Poland

Head of the Department: Prof. Piotr Gutowski MD, PhD

${ }^{3}$ Anaesthesiology, Perioperative Medicine, and Pain Therapy Department, HELIOS Hospital, Berlin, Germany

Key words: risk assessment, premedication, Helios Score.

Słowa kluczowe: ocena ryzyka, premedykacja, skala Helios.

\begin{abstract}
Introduction: Optimal risk assessment and medical preparation before surgery is still a problem.

Aim of the research: To compare the adequacy of periprocedural risk assessment performed by an anaesthesiologist during premedication, with the same assessment made by a nurse using the Helios Score in successive patients in the Department of Vascular Surgery.

Material and methods: A total of 185 patients qualified for open vascular surgery in the Vascular Surgery Department of the Pomeranian Medical University in the first quarter of 2018 were studied. The group consisted of patients qualified for surgical treatment with high $(n=65)$, medium $(n=42)$, and low $(n=78)$ operational risk. Retrospective analysis of the prediction accuracy between two methods was performed. There was a comparison between anaesthetist pre-assessment and Helios Score used by the nurse team. The prediction accuracy of death and complication rates were compared between those two methods.

Results: In the analysed period there were seven deaths and 26 cases of general deterioration. In 152 cases, no complications were found. Differences in sensitivity in prediction between anaesthetist and a nurse using the Helios Score were, respectively: death $15 \%$ vs. $5.5 \%$ ( $p=0.283)$, complications $35 \%$ vs. $9.2 \%(p=0.036)$. Simultaneous used of expert assessment and Helios Score could increase the prediction of the death rate to $71 \%$.

Conclusions: The Helios Score helps the nurse team to recognise high-risk patients. Additional use of the Helios Score increases the efficacy of detection of high-risk patients.
\end{abstract}

\section{Streszczenie}

Wprowadzenie: Identyfikacja pacjentów z podwyższonym ryzykiem okołozabiegowym jest warunkiem efektywnej optymalizacji leczenia. Znalezienie najbardziej wyważonej metody optymalizacji leczenia przed zabiegiem chirurgicznym wciąż stanowi wyzwanie. Powszechnie postuluje się przewagę doświadczenia klinicysty nad walidowanymi skalami służącymi ocenie ryzyka leczenia.

Cel pracy: Porównanie adekwatności oceny ryzyka okołozabiegowego dokonywanej przez anestezjologa z oceną dokonywaną przez pielęgniarkę przy użyciu skali Helios u pacjentów przyjętych kolejno na oddział chirurgii naczyniowej.

Materiał i metody: Stu osiemdziesięciu pięciu chorych poddano leczeniu rewaskularyzacyjnemu w Klinice Chirurgii Naczyniowej Pomorskiego Uniwersytetu Medycznego w pierwszym kwartale 2018 r. Grupę badana stanowili pacjenci zakwalifikowani do leczenia operacyjnego o wysokim $(n=65)$, średnim $(n=42)$ oraz niskim $(n=78)$ ryzyku operacyjnym. Przeprowadzono retrospektywną analizę danych. Porównano skuteczność przewidywania zgonu i powikłań przez anestezjologa podczas premedykacji z oceną pielęgniarską wspartą skalą Helios.

Wyniki: W badanym okresie odnotowano 7 zgonów i 26 przypadków pogorszenia stanu ogólnego. W 152 przypadkach nie stwierdzono żadnych powikłań. Czułość wykrywania zgonu przez anestezjologa w porównaniu z pielęgniarką posługującą się skalą Helios wyniosła $15 \%$ vs 5,5\% ( $p=0,283)$, a powikłań 35\% vs 9,2\% $(p=0,036)$. Jednoczesne zastosowanie oceny eksperta i skali Helios może zwiększyć czułość wykrywania ryzyka zgonu do ponad $71 \%$.

Wnioski: Skala Helios pozwala pielęgniarce adekwatnie ocenić ryzyko leczenia naczyniowego u pacjenta. Dodatkowe wsparcie skalą Helios zwiększa czułość wykrywania wysokiego ryzyka operacyjnego. 


\section{Introduction}

Detection of patients with increased risk of periprocedural conditions is a prerequisite for effective optimisation of treatment [1]. On the other hand, ordering unnecessary specialist consultations does not improve results but generates costs [2-4]. Finding the most balanced method of optimising treatment before surgery is still a challenge. The clinician's experience of validated scales, which is used to assess the risk of treatment, is commonly postulated.

\section{Aim of the research}

The aim of the study was to compare the adequacy of periprocedural risk assessment performed by an anaesthesiologist during premedication with the same assessment made by a nurse using the Helios Score, in successive patients in the Department of Vascular Surgery.

\section{Material and methods}

A retrospective analysis of clinical data of patients treated in the Vascular Surgery Department of Pomeranian Medical University from 1.01.2018 to 30.03.2018 was performed. The group consisted of 185 patients qualified for vascular treatment using a hybrid or "open" technique. Patients qualified for intravascular treatment were excluded (because they were not subject to the expert's assessment, i.e. they were not subjected to anaesthesiological premedication).

Two methods of screening of patients used in the search for patients with an increased risk of surgical treatment were compared. The first method was direct evaluation by the anaesthetist during premedication (expert assessment). The anaesthesiologist assessed the risk according to their own informal criteria and recommended additional consultations or optimisation of the treatment before the surgery.

The second method was risk assessment by a nurse based on risk classification according to the Helios Score [2].

The Helios Score includes clinical data as in Figure 1.

The score summary qualifies patients for low-risk groups $\leq 6$ points, intermediate-risk group $=7$, and high-risk group $\geq 8$. According to the standard of this scale, patients with high or medium perioperative risk should be treated as potential candidates for specialist consultations because they may require optimisation of treatment before surgery $[1,2]$.

\section{Statistical analysis}

A comparison of countable variables was made using the exact Fisher test. Differences were considered statistically significant at $p<0.05$. The statistical analysis was carried out using the Statistica program (version 13, StatSoft, Dell, Round Rock, Texas, USA).

\section{Results}

The following surgical procedures were performed in the study group: open artery surgery/stent-graft implantation - 3/21, aorto-bifemoral implant surgery -5 , hip joint/hybrid iliac artery - 18/4, acute ischaemia treatment -6 , amputation or necrosis -22 , patency of the carotid arteries / other treatments on the arteries of the aortic arch of the aorta $-55 / 3$, femoropopliteal bypass -33 , profundoplasty -13 , and implantation of stent-graft into the thoracic aorta -2 . The remaining patients underwent conservative treatment.

One hundred and fifty-two cases were treated without complications. In the given period there were seven deaths and 26 cases of general deterioration due to complications.

\section{Opinion of an expert (anaesthetist)}

During premedication, anaesthesiologists identified 20 patients with increased operative risk and ordered 20 specialist consultations (including two internists, one dental, one ENT, one nephrological, one neurological, and 14 cardiac).

Seven patients required additional optimisation of pre-operative treatment. Despite this, 2 patients died in this group, and four had complications. According to an expert (anaesthetist), no consultation or optimisation of treatment was needed in 165 cases. Nurse's rating according to the Helios Score.

According to the assessment made by the nurse, on the basis of the Helios Score, 54 patients had a high risk in the procedure. On the other hand, average risk was evaluated in one patient and low in 131 patients (Table 1).

The percentage of deaths envisaged by the anaesthetist was in total $43 \%$ (three out of seven found) and $27 \%$ (seven out of 26 ).

The rate provided by the Helios Score equal up to $43 \%$ (three out of seven) and 19\% (five out of twenty sixth), respectively (Table 2 ).

With simultaneous use of the expert's experience (an anaesthesiologist considers that the consultation is needed) and Helios Score support (high and medium risk assessed by the nurse), 69 cases could have been be distinguished.

This group would include $71 \%$ of deaths (5/7) and $42 \%$ of complications (11/69). The percentage of unnecessarily ordered consultations would remain at the same level of $63 \%$.

Differences between the simultaneous use of both predictive methods were not statistically significant.

\section{Discussion}

The expert's experience is based on subconsciously or deliberately using different risk assessment scales, such as ASA, Goldman, Lee, and others [1, 5-8]. Clinical experience (the so-called "clini- 


\section{EVALUATION RISK ASSESSMENT SCALE}

\section{Name}

Surname

Patient ID

FOR ANESTHETIST

\section{Diseases and symptoms that increase the risk}

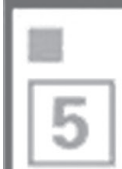

HIGH RISK, e.g.

- acute coronary syndrome

- myocardial infarction $<30$ days

- angina at slight exertion

and at rest (NYHA 3-4)

- decompensated heart failure

- 3-4 grade valve defects

-respiratory failure

- MOF

- shock

MODERATE RISK, e.g.

- angina at high exertion (NYHA 1-2)

- history of a heart attack or stroke

- peripheral artery disease

- decompensation of a history of

heart failure

- diabetes

- renal failure $s r>1.5 \mathrm{mg} / \mathrm{dl}$

- hepatic insufficiency / cirrhosis

LOW RISK, e.g.

- age> 75 years

- non-specific ECG changes

- lack of sinus rhythm (eg AF)

- hypertension (SBP> 180, DBP> 110)

NO EXCESSIVE RISK
FOR SURGEON

Operations that increase risk

HIGH RISK, e.g.
-sudden surgery in the abdominal cavity and chest

- surgery of the aorta and large vessels

- operation of the lower limbs in ischemia

- large oncological treatments

- high blood loss is expected

MODERATE RISK, e.g.

- carotid artery surgery

- endovascular aortic surgery

- plasty of peripheral arteries

- amputation

- surgery: knees, hips, spine

- planned pelvic surgery

- large oncological surgery in surgery

ENT

- neurosurgery

- large urological gynecological procedures

- intraperitoneal surgery

LOW RISK, e.g.

- superficial operations

- endoscopic operations

- breast surgery

- ophthalmic surgery

- small and medium dental shopping

- varicose veins operations

- small urological and gynecological opera-

tions

Endocrine surgeries - thyroid gland

Date

Signature of the surgeon

Signature of the aneathetist

RISK SCALE = SUM OF POINTS

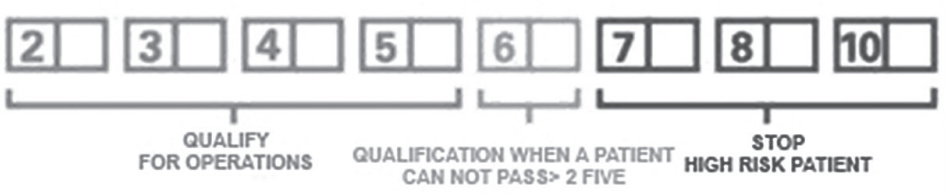

\section{WARNING!}

Double Antiplate Therapy in the perion $<4$ Weeks

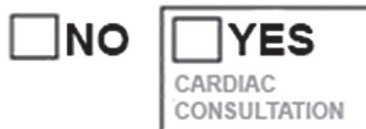

\section{HIGH RISK PATIENT}

\section{SURGERY Yes Postponement}

Date

Signature of the anesthetist

Figure 1. Helios Score 
Table 1 . Sensitivity of compared methods of risk assessment

\begin{tabular}{|lccc|}
\hline Parameter & $\begin{array}{c}\text { The anaesthesiologist ordered } \\
\text { consultation/optimisation } \\
(n=20) \\
n(\%)\end{array}$ & $\begin{array}{c}\text { Helios Score } \\
\text { High or medium risk } \\
(n=55)\end{array}$ & $P$-value \\
Death & $3(15)$ & $3(\%)$ & 0.283 \\
Complications of treatment & $7(35)$ & $5(9.2)$ & 0.036 \\
Unnecessary consultation & $13(65)$ & $49(89)$ & 0.283 \\
\hline
\end{tabular}

$P$-value - statistical significance, $n$ - number.

Table 2. Specificity of compared risk assessment methods

\begin{tabular}{|lccc|}
\hline Parameter & $\begin{array}{c}\text { The anaesthesiologist ordered } \\
\text { consultation/optimisation } \\
(n=165) \\
n(\%)\end{array}$ & $\begin{array}{c}\text { Helios Score } \\
\text { Low risk } \\
(n=131) \\
n(\%)\end{array}$ & $P$-value \\
Death & $4(2.4)$ & $4(3)$ & 0.509 \\
Complications of treatment & $19(11.5)$ & $20(15.2)$ & 0.512 \\
\hline
\end{tabular}

$P$-value - statistical significance, $n$ - number.

cal nose") often has higher sensitivity and specificity than the most optimally matched scales, because none of them is able to include all the parameters that affect the result.

However, scales are needed as a benchmark for less experienced clinicians. They can be used successfully by both a doctor and a nurse. An example of scaling the urgency of intervention is the EWS Score [9]. The Helios scale is widely used in the German HELIOS Kliniken Concern as a premedicational scale. Attempts to transfer it to Poland (Lublin) are also taking place [2]. It is an easy-to-use and universal scale. Our analysis shows that the nurse equipped with this tool equitably assessed the perioperative risk in patients, as well as the premedicating preoperative anaesthesiologist. It allows the detection of patients with increased perioperative risk, suggesting the need for specialist consultations, changing qualifications, or optimising treatment. In addition, we noticed that simultaneous but independent (an anaesthesiologist separately and nurse separately) use of two methods of risk assessment would significantly increase the sensitivity of detecting patients at high risk of death without increasing the percentage of costly specialist consultations.

\section{Limitation}

The typical limitation is the retrospective character of our analysis and lack of randomisation between assessed methods. Nevertheless, our analysis has a pioneering nature due to the lack of validation of HELIOS score in the Polish population.

\section{Conclusions}

The Helios Score allows nurses to adequately assess the risk of treating a vascular patient. Additional support with the Helios Score can increase the sensitivity of detecting patients with high operational risk.

\section{Conflict of interest}

The authors declare no conflict of interest.

\section{References}

1. Bauer SM, Cayne NS, Veith FJ. New developments in the preoperative evaluation and perioperative management of coronary artery disease in patients undergoing vascular surgery. J Vasc Surg 2010; 51: 242-251.

2. Kazimierczak S, Kazimierczak A, Rynio P, Żukowski M. Preoperative evaluation: new attempt. Pol Prz Chir 2015; 87: 644-654.

3. Kazimierczak A, Nikodemski T, Gutowski P, Kazimierczak S, Guzicka-Kazimierczak R, Jędrzejczak T, Śledź M, Cnotliwy M. Perioperative treatment standard use in Vascular Surgery Department of Pomeranian Medical University. Opieka Okołooperacyjna 2011; 2: 18-23.

4. Wijeysundera DN, Austin PC, Beattie WS, Hux JE, Laupacis A. Outcomes and processes of care related to preoperative medical consultation. Arch Intern Med 2010; 170: 1365-1374.

5. Kazimierczak A, Śledź M, Gutowski P, Guzicka-Kazimierczak R, Cnotliwy M, Zeair S, Samad R. Efficacy of P-POSSUM calculator in prediction of early results and cost of treatment in vascular surgery. Chir Pol 2010; 12: 59-66.

6. Kazimierczak A, Śledź M, Guzicka-Kazimierczak R, Gutowski P, Cnotliwy M. Early death in vascular surgery: an ongoing prognostic problem. Ann Acad Med Stetin 2010; 56: 87-94. 
7. Kazimierczak A, Kazimierczak S, Guzicka-Kazimierczak R. What is the best way to assess operative risk for the patient treated in the vascular department? Opieka Okołooperacyjna 2011; 1: 50-53.

8. Rix TE, Bates T. Pre-operative risk scores for the prediction of outcome in elderly people who require emergency surgery. World J Emerg Surg 2007; 2: 16.

9. Kyriacos U, Jelsma J, Jordan S. Monitoring vital signs using early warning scoring systems: a review of the literature. J Nurs Manag 2011; 19: 311-330.

\section{Address for correspondence:}

Anita Rybicka PhD

Department of Nursing

Faculty of Health Sciences

Pomeranian Medical University in Szczecin

ul. Żołnierska 48, 71-210 Szczecin, Poland

E-mail: anitarybicka@onet.eu 